\title{
FIRST-TIME ADVISORY EXPERIENCE OF HUSBANDS DURING LABOR TIME OF PREGNANCY: A SCOPING REVIEW
}

\author{
Nuristy Brillian Ainindyahsari Winarna, Andari Wuri Astuti
}

Faculty of Public Health, Universitas ‘Aisyiyah Yogyakarta

\begin{abstract}
Background: Mothers experienced enormous physical and emotional changes, especially during childbirth. Birth support role of husbands reassured both husband and wife about labor and birth. This study aimed to review the first-time advisory experience of husbands during labor time of primigravida wife.

Subjects and Method: A scoping review method was conducted in eight stages including (1) Identification of study problems; (2) Determining priority problem and study question; (3) Determining framework; (4) Literature searching; (5) Article selection; (6) Critical appraisal; (7) Data extraction; and (8) Mapping. The search included ScienceDirect, Wiley Online Library, ProQuest, and grey literature through Google Scholar search engine databases. The inclusion criteria were English/ Indonesian-language and full-text articles in peer-reviewed journals published between 2009 and 2019. A total of 543,111 articles were obtained by the searched database. After the review process, six articles were eligible for this review. The data were reported by the PRISMA flow chart.

Results: Six articles from developed countries (Australia, Sweden, Singapore, Israel, and England) met the inclusion criteria with qualitative and quantitative (cross-sectional) studies. Three main aspects discussed were support, challenges, and psychological conditions of experience of husbands during labor time of pregnancy. Support of husbands was identified as physical and moral. Challenges faced by husbands included lack of preparedness, knowledge, and encouragement from health care professionals. Psychological conditions of satisfaction and concern were found in husbands' transition to fatherhood.

Conclusion: Responsibility, emotion, experience, and barrier of husbands are related to maternal health problems. Better involvement of fathers will be able to enhance better quality of relationships and family health through understanding, experience, and assistance, especially in the childbirth process.
\end{abstract}

Keywords: advisory, husbands, experience, labor, pregnancy

\section{Correspondence:}

Nuristy Brillian Ainindyahsari Winarna. Universitas 'Aisyiyah Yogyakarta. Jl. Siliwangi (Ring Road Barat) No 63 Mlangi, Nogotirto, Gamping, Sleman, Yogyakarta, 55292. Email: nuristybrilliano2@gmail.com. Mobile: +6285338800207. 